\title{
Mediating role of port supply chain integration between involvement of human resource practices and port performance in Kingdom of Saudi Arabia
}

\author{
Mohameed Saud Mira $^{a^{*}}$, Yap Voon Choong ${ }^{a}$ and Chan Kok Thim ${ }^{a}$
}

${ }^{a}$ Faculty of Management, Multimedia University, Kualalumpur, Malaysia

\begin{tabular}{lll}
\hline C H R O N I C L E & A B S T R A C T \\
\cline { 1 - 1 } $\begin{array}{l}\text { Article history: } \\
\text { Received October 2, } 2018\end{array}$ & $\begin{array}{l}\text { The primary objective of this paper is to investigate the mediation role of port supply chain } \\
\text { integration between Human Resource Management (HRM) practices and port performance (PP) }\end{array}$ \\
Accepted November 232018 & $\begin{array}{l}\text { in Kingdome of Saudi Arabia. The present study employed partial lest square structural equation } \\
\text { Available online }\end{array}$ & $\begin{array}{l}\text { modeling technique to analyze the collected data. The study found some positive significant } \\
\text { direct relationship between HRP, port supply chain integration (PSCI) and PP. Besides, this study }\end{array}$ \\
November 23 2018 & also found some positive and significant relationship between HRP and PSCI. Additionally, the \\
Keywords: & study confirms the mediating role of PSCI between HRP and PP. The study contributes to the \\
Human Resource Practices & literature and to the practice of ports to understand how the process of HRP and PSCI produces \\
Port performance & better port performance.
\end{tabular}

(C) 2019 by the authors; licensee Growing Science, Canada

\section{Introduction}

\subsection{Background}

The ports have major economic and strategic importance for countries as they facilitate imports and exports by having connected geographical locations, subsequently fostering the local, national and regional economy and boosting firm's competitiveness along the entire global supply chain (Song \& Parola, 2015). In the context of Kingdom of Saudi Arabia (KSA) that is the world's main oil exporting country, it has the largest and most diversified economy in the Middle East with industrial exports that are internationally oriented. The KSA should have efficient, fully equipped ports that are capable of doing the job as it should be accomplished. The ports play a great role to increase the economy of the country through handling the cargo of goods for imports and exports. According to Elentably (2015) nine main ports are working in KSA, which achieved $95 \%$ of the exports and imports of commodities through the Kingdom's seaports while $55 \%$ of the cargos handled are exported. In addition, more than 5 million Twenty-Foot Equivalent Unit (TEUs) are handled annually and 11,000 ships visit Saudi ports annually (Elentably, 2015). Despite the positive contribution to growth domestic product of Saudi Arabia, cargo's over stock is the main issue that recently came up which raise the price of cargo's

* Corresponding author

E-mail address: mereh3000@hotmail.com (M.S. Mira)

(C) 2019 by the authors; licensee Growing Science, Canada doi: $10.5267 /$ j.uscm.2018.11.005 
handle up to $200 \%$ and resulted in lack of HRM practices such as employee recruitment \& selection, employee participation and port supply chain integration (PSCI) in cargo section (News, 2016).

The port is regarded as a significant player in global logistics and supply chain since it handles over $90 \%$, in terms of volume, of cargoes transported over the globe (Mangan et al., 2016). However, the growing demand for the integrated logistics serves ad intensifying port competition and a port should collaborate and cooperate with its supply chain partners for providing value-added services to port users (Wang \& Cheng, 2010). Moreover, the concept of PSCI is gaining importance in port sector. There are many studies that stated the importance of port in supply chain management (Bichou \& Gray, 2004; Pettit \& Beresford, 2009). Nevertheless, it is not clear that PSCI is limited, whichever to labor supplier and equipment or shipping lines and inland transport operators. However, there are very limited studies on the relationship between PSCI and port performance.

\section{Literature Review and Hypothesis Development}

This section will cover the past studies discussions related to port supply chain integration (PSCI), human resource practices (HRM) and port performance (PP). Furthermore, this portion will cover the discussion on the relationship between the proposed variables to develop the hypotheses.

\subsection{Port performance (PP)}

Port performance is optimizing the connectivity, efficient operation, value added service and cost efficiency over the competitor which could lead to competitive advantage (Notteboom \& Rodrigue, 2005). The enhancement of PP marginally contributes to country development through economic benefits and attracting more port users (Tongzon \& Sawant, 2007). PP is primarily concerned with efficiency and effectiveness of the services. However, the meaning of full assessment of PP requires a set of antecedents of port operations and port user interest such as connectivity, safety \& security, value added service, cost efficiency, convenience of port users and cost efficiency. The objective of this paper is to investigate the antecedents of PP empirically, such as HRM practices and PSCI.

\subsection{Human Resource Practices (HRP) and Port Performance (PP)}

Human resource practices could be deployed for competitive advantage leading to higher port performance (Schuler \& MacMillan, 1984). In other words, any successful organization depends on employee performance within the firm. HRP is the multilevel construct that captures the specific activities within the firm (Arthur \& Boyles, 2007). Moreover, HRP gives information to employees on how they will be selected, how they will interact with customers and firms and how they will be rewarded. However, when these practices are well aligned and integrated that creates a strong HRM system within the firm. The current study considers two main influential practices of HRM, which are employee recruitment and selection and employee participation.

The function process to attract and select the skilled workers to reach the goals of the organizations, once the organization attracts and chooses the employees, the organization will achieve its goals in low cost. However, the wrong process of this function will affect the performance of the firms, in addition, the recovery of it will be costly. Thus, the main aim of this function is to gain the goal of the organization based on attracting and selecting the right employees (Gamage, 2014).

On the other hand, employee participation (EP) demonstrates the structure of flat organization that gives value to employee's opinion. Furthermore, EP helps the employee learn on how to improve his/her job and receives desire performance or reward. However, there are two ways to improve the employee participation and their performance such as problem-solving group and feedback. Problem solving groups present the firm structure and give a chance to employees for participation and giving feedback information delivering to employee that allow the employees to improve their performance and use the feedback to adjust their efforts. Therefore, in this way employee participation indicates how 
employees are participating in the firm. This activity is very important for any firm performance; thus, this HR practice considers for port performance as influential factor.

Therefore, the following the hypothesis propose;

$\mathbf{H}_{1}$ : There is a significant relationship between human resource practices (HRP) and port performance.

\subsection{Human Resource Practices (HRP) and Port Supply Chain Integration (PSCI)}

Past studies stressed that HRP facilitates building PSCI relationships and collaboration (Scarbrough, 2000). In more explanations, high incentives to employees are expected to yield desire supply chain behavior, further, human capital can be leveraged to improve the firm supply chains. Moreover, skill and competency of employee enhance the supply chain management. Additionally, supply chain integration is the heart of supply chain management. The objective of this study is to investigate the role of HRP in SCI. However, in this respect, the study of Huo et al. (2015) gives some valid evidence that HRP influences PSCI, positively.

Furthermore, Shub and Stonebraker (2009) found the relationship between HRP and PSCI and further stressed that a relationship between HRP and PSCI must be established. In another study, Menon (2012) presented that the specific HR practice such as recruitment and selection improve the PSCI. Additionally, one more study found the HRP components such as employee participation influences positively on the port supply chain integration. Therefore, based on the past literature review discussion, the following hypothesis is proposed.

$\mathbf{H}_{2}$ : There is a significant relationship between human resource practices and port performance.

\subsection{Mediating the role of port supply chain integration (PSCI) between human resource practice (HRP)} and port performance (PP)

Port supply chain integration (PSCI) is the process in which firm can coordinate and interconnected inter-organizational and intra-organizational processes. PSCI emphasizes the link between the firm and customers, suppliers and other channel members. Additionally, PSCI is the center of coordination, which requires all business process be streamline internally within the firm and externally among other firms. However, PSCI has been gaining importance day by day due to its contribution towards firm competitive advantage which leads to firm performance such as port performance. Moreover, PSCI conceptualization can be divided into two dimensions including customer integration and supplier integration. Besides, the relationship between PSCI and PP has been investigated in the past studies. Han (2018) investigated the relationship between PSCI and PP and found a significant and positive relationship between PSCI and PP. In another study, Thai and Jie (2018) stated that supply chain integration had positive influence on firm performance in terms of service quality. On this argument the current study proposed the following hypothesis,

$\mathbf{H}_{3}$ : There is a significant relationship between human resource practices and port performance.

In respect to mediating role of PSCI, the current study considers PSCI as a mediating variable between HRP and PP. Basically, PSCI is found to have positive relationship in past studies with HRP and with PP (Preacher et al., 2007). Furthermore, the mediating variable can be used to explain the relationship between HRP and PP. Moreover, there are very limited studies on the role of PSCI between HRP and PP. The present study proposes the following hypothesis,

$\mathbf{H}_{4}$ : Port supply chain integration plays the mediating role between human resource practices and port performance. 


\subsection{Framework}

The current study framework consists of one exogenous variable; namely HRP with two dimensions of recruitment and selection and employee participation. The study has one mediating variable; namely port supply chain integration with two dimensions such as customer integration and supplier integration and the study has one endogenous variable; namely port export performance.

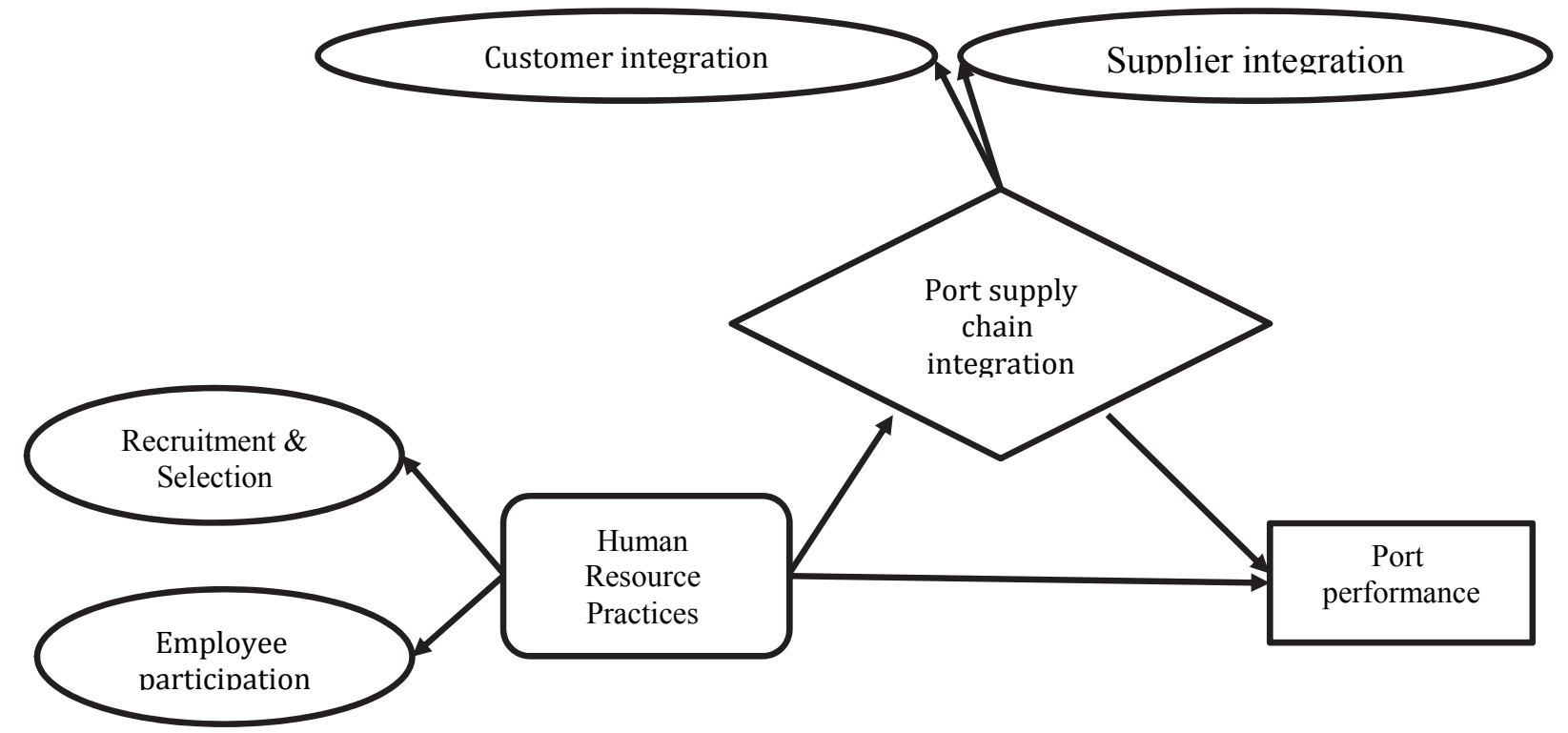

Fig.1. Study framework

\section{Research methodology}

The presented study selected the firms for the response which are engaged in container logistics in Kingdome of Saudi Arabia (KSA). The current study used the directory of port authority KSA to identify the firms such as the terminal operators, shipping lines, inland transport companies, freight forwarders, ship management companies and third-party logistics providers. However, they were chosen as proxy for balance view between HRP, PSCI and PP users (Bichou \& Bell, 2007). The target population are located at major nine ports of the KSA including Jeddah Islamic Port, King Abdulaziz Port Dammam, King Fahad Industrial Port Yanbu, King Fahad Industrial Port Jubail, Jubail Commercial Port, Yanbu Commercial Port, Jizan Port, Dhiba Port, Ras Al-Khair Port. The current study distributed 600-web based questionnaires with two reminders of e-mail messages and telephonic calls to get the higher responses, however, the present study has received 221 useable responses, which yields a response rate of $36 \%$. The questionnaire of the study was adapted from the past studies such as 8 items scale of HRP adapted from Huo et al. (2015) and Sánchez-Marín et al. (2017), 8 items scale of PSCI adapted from Flynn et al. (2010) and at last 9 items scale of PP adapted from Seo et al. (2016), the scale can be seen in appendix 1 . The seven Likert scale has been used in the questionnaire.

\section{Data analysis and results}

SmartPLS-3 was employed for the analysis of partial least square structural equation modeling (PLSSEM). The two-step approached such as measurement model and structural model has been taken for in this study but the assessment of measurement and structural model were discussed in details.

\subsection{Measurement Model}

In this step, measurement model is used to evaluate the construct reliability and validity. The measurement model used different criteria to validate the construct reliability and validity such as Cronbach alpha, composite reliability and average variance extracted (AVE) criteria are used to measure the constructs 
reliability. However, the values of Cronbach alpha and composite reliability should be less than 0.70 and AVE should be more than 0.50 (Hair et al., 2014). Thus, the current study construct reliability achieved the threshold values and result can be seen in Table 1 and Fig 2.

Table 1

Finding of the measurement model (First Order, Reflective)

\begin{tabular}{llll}
\hline Constructs & Cronbach's Alpha & Composite Reliability & AVE \\
\hline Customer integration & 0.719 & 0.794 & 0.576 \\
Employee participation & 0.897 & 0.919 & 0.619 \\
Port performance & 0.924 & 0.937 & 0.624 \\
Recruitment \& selection & 0.83 & 0.897 & 0.745 \\
Supplier integration & 0.739 & 0.736 & 0.507 \\
\hline
\end{tabular}

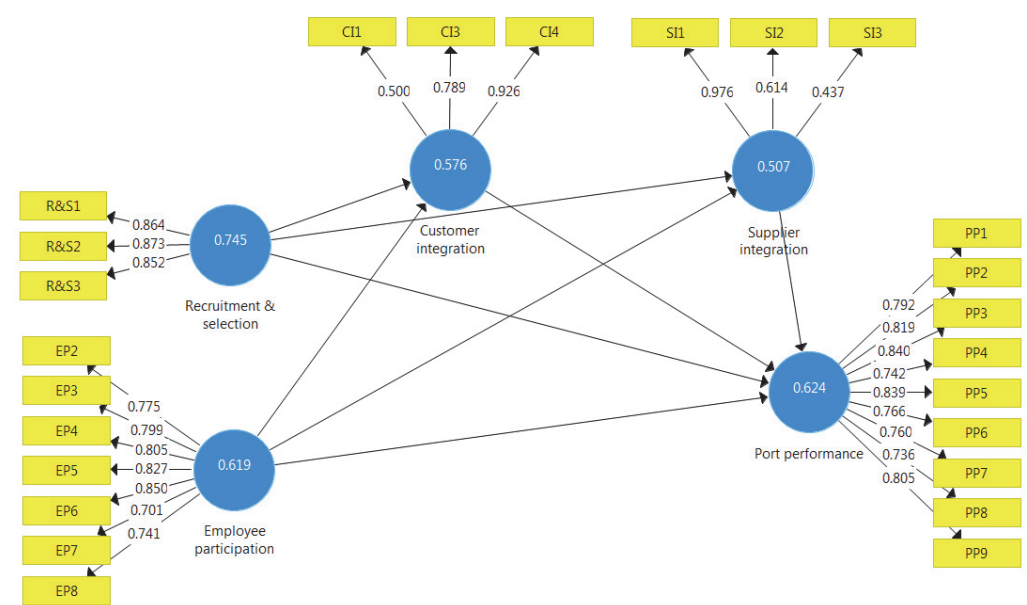

Fig. 2. Measurement Model (Items loading and AVE)

Furthermore, in terms of the construct validity, measurement model used the Heterotrait-Monotrait ratio of correlations (HTMT) criteria to be validated the validity of all constructs of the study. The values of HTMT should be less one 1, thus all values of the current study constructs were less than 1 (Henseler et al., 2015), the results can be seen in Table 2. Therefore, the measurement model is validated. After the validation of measurement model, the current study can go for structural model assessment to make decision regarding hypothesis acceptance or rejection.

Table 2

Heterotrait-Monotrait Ratio (HTMT)

\begin{tabular}{llllll}
\hline Constructs & $\begin{array}{l}\text { Customer } \\
\text { integration }\end{array}$ & $\begin{array}{l}\text { Employee } \\
\text { participation }\end{array}$ & $\begin{array}{l}\text { Port } \\
\text { performance }\end{array}$ & Recruitment \& selection & $\begin{array}{l}\text { Supplier } \\
\text { integration }\end{array}$ \\
\hline $\begin{array}{l}\text { Customer integration } \\
\text { Employee participation }\end{array}$ & 0.493 & & & \\
Port performance & 0.557 & 0.837 & & \\
Recruitment \& selection & 0.385 & 0.433 & 0.481 & \\
Supplier integration & 0.869 & 0.304 & 0.385 & 0.381 & \\
\hline
\end{tabular}

\subsection{Structural Model Assessment}

The structural model assesses through three criteria such as path co-efficient for hypothesis acceptance or rejection, $R^{2}$ for all variable contribution into endogenous variable and $f^{2}$ for construct individual contribution values into $R^{2}$. In respect to path coefficient, Henseler et al. (2009) stated that, the path coefficients are like regression analysis and standardized beta coefficient. The rule of thumb revealed by Hair et al. (2014), which explains that Bootstrapping method was performed (with 5000 sampling iterations for 221 respondents) to determine the beta-values of the coefficient of the regression and $t-$ values which should be greater than 1.96 to confirm the results. The main objective of the present study 
is to evaluate the relationship between the constructs. The results of path coefficient show positive and significant relationships among HRP, PSCI and PP. The results can be seen in Table 3.

Table 3

Direct relationship between construct

\begin{tabular}{llllll}
\hline Hypothesis & Beta & SD & T Values & P Values & Decision \\
\hline H1: Human resource practices $\rightarrow$ Port performance & 0.755 & 0.031 & 24.021 & 0.000 & Accepted \\
H2: Human resource practices $\rightarrow$ Port supply chain integration & 0.580 & 0.049 & 11.892 & 0.000 & Accepted \\
H3: Port supply chain integration $\rightarrow$ Port performance & 0.328 & 0.062 & 5.265 & 0.000 & Accepted \\
\hline
\end{tabular}

Furthermore, the mediating role of PSCI was analysed and found a positive and significant mediating role PSCI between HRP and PP. The results can be seen in Table 4.

Table 4

Indirect relationship (Mediation)

\begin{tabular}{llllll}
\hline Hypothesis & Beta & SD & T Values & P Values & Decision \\
\hline $\begin{array}{l}\text { H4: Human resource practices } \rightarrow \text { Port supply } \\
\text { chain integration } \rightarrow \text { Port performance }\end{array}$ & 0.19 & 0.038 & 4.971 & 0.000 & Accepted \\
\hline
\end{tabular}

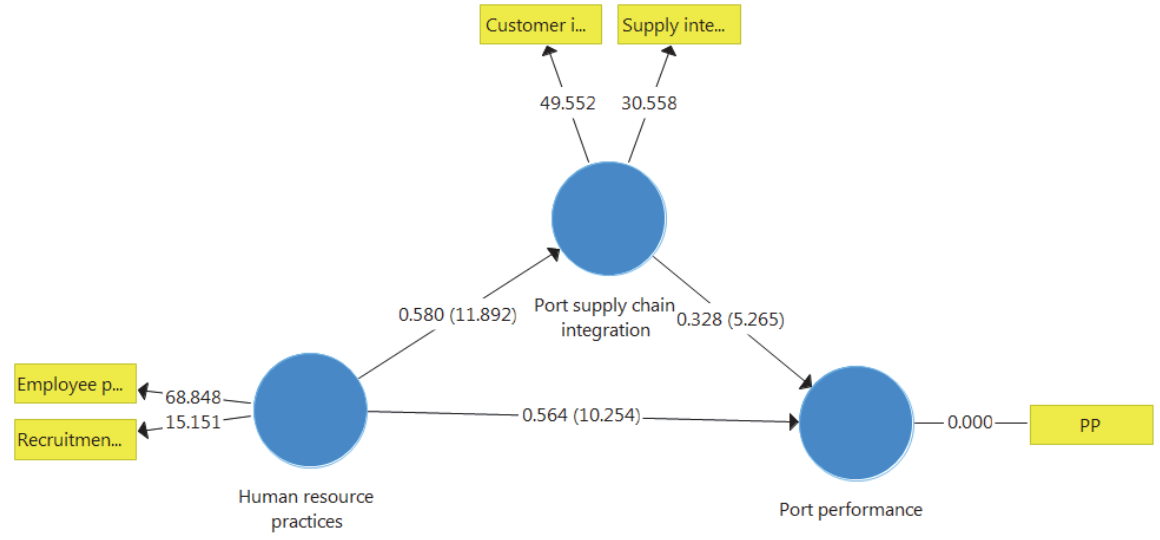

Fig. 3. Structural Model

Furthermore, in respect of mediation type, the study used the Fig. 3 according to Nitzl et al. (2016) and recognized the partial mediating role of PSCI between HRP and PP.

Besides, the second criteria are $R^{2}$, which shows the contribution of all endogenous variables in endogenous variable. However, in respect to $R^{2}$, the values of $R^{2}=0.25$ is considered weak, 0.50 is considered moderate and 0.75 is considered excellent. Hence the $R^{2}$ of PP is recorder moderated and $R^{2}$ of PSCI is founded weak. The third criteria for structural model assessment is the effect size $\left(f^{2}\right)$, however, in term of $f^{2}$ values that considered small (0.02), medium $(0.15)$ and large $(0.35)$ respectively. Therefore, the study found the $f^{2}$ of HRP is larger and PSCI $f^{2}$ around medium. The results of $\mathrm{R}^{2}$ and $f^{2}$ can be found in Table 5.

\section{Table 5}

The result of $R^{2}$ and $f^{2}$

\begin{tabular}{llllll}
\hline Constructs & $f^{2}$ & & $R^{2}$ \\
\cline { 2 - 6 } & $\begin{array}{l}\text { Human resource } \\
\text { practices }\end{array}$ & $\begin{array}{l}\text { Port } \\
\text { performance }\end{array}$ & $\begin{array}{l}\text { Port supply chain } \\
\text { integration }\end{array}$ & $\begin{array}{l}\text { Port supply chain } \\
\text { integration }\end{array}$ & $\begin{array}{l}\text { Port } \\
\text { performance }\end{array}$ \\
\hline Human resource practices & & 0.588 & 0.508 & 0.333 & 0.641 \\
Port supply chain integration & & 0.199 & & & \\
\hline
\end{tabular}




\section{Discussion and conclusion}

The present study has shown a positive and significant relationship between HRP, PSCI and PP, hence the hypotheses $\mathrm{H}_{1}, \mathrm{H}_{2}$ and $\mathrm{H}_{4}$ have been accepted. The results are consistent with past studies (e.g. Gamage, 2014; Han, 2018; Huo et al., 2015). Moreover, the present study has found a mediating role of PSCI between HRP and PP, hence the hypothesis $\mathrm{H}_{4}$ has been accepted. Therefore, the current exogenous variables have had influential role into enhancement of port performance in context of Saudi Arabia. Moreover, HRP is considered to have more influential variable in this study, it did not have only direct relationship with PP but maintained indirect relationship with PP through PSCI. Furthermore, all relationships shown with beta value have had positive and direct relationships with PP, which means when HRP and PSCI increased, PP increased too. Thus, the current study suggests to owners / managers to implement the HRP, PSCI to improve the PP. Moreover, these variables are considered more important in the context of KSA. The port authority and government of KSA should take serious notes to consider these variables during decision making to improve PP. Additionally, this framework was validated in one country, cross cultural study would also be appreciated. Moreover, future study should validate the current study framework in manufacturing industry and should adapt the longitudinal method to validate the current study findings as well.

\section{References}

Arthur, J. B., \& Boyles, T. (2007). Validating the human resource system structure: A levels-based strategic HRM approach. Human Resource Management Review, 17(1), 77-92.

Bichou, K., \& Bell, M. G. (2007). Internationalisation and consolidation of the container port industry: assessment of channel structure and relationships. Maritime Economics \& Logistics, 9(1), 35-51.

Bichou, K., \& Gray, R. (2004). A logistics and supply chain management approach to port performance measurement. Maritime Policy \& Management, 31(1), 47-67.

Elentably, A. (2015). Strategic and Operational Plan Implementation of Seaports (Utilization Jeddah Port). TransNav: International Journal on Marine Navigation and Safety of Sea Transportation, 9.

Flynn, B. B., Huo, B., \& Zhao, X. (2010). The impact of supply chain integration on performance: A contingency and configuration approach. Journal of Operations Management, 28(1), 58-71.

Gamage, A. S. (2014). Recruitment and selection practices in manufacturing SMEs in Japan: An analysis of the link with business performance. Ruhuna Journal of Management and Finance, 1(1), 37-52.

Hair, J. F., Hult, G. T. M., Ringle, C. M., \& Sarstedt, M. (2014). A Primer on Partial Least Squares Structural Equation Modeling (PLS-SEM). Los Angeles, CA: SAGE.

Han, C.-h. (2018). Assessing the impacts of port supply chain integration on port performance. The Asian Journal of Shipping and Logistics, 34(2), 129-135.

Henseler, J., Ringle, C. M., \& Sarstedt, M. (2015). A new criterion for assessing discriminant validity in variance-based structural equation modeling. Journal of the Academy of Marketing Science, 43(1), 115-135.

Henseler, J., Ringle, C. M., \& Sinkovics, R. R. (2009). The use of partial least squares path modeling in international marketing New challenges to international marketing (pp. 277-319). Emerald Group Publishing Limited.

Huo, B., Han, Z., Chen, H., \& Zhao, X. (2015). The effect of high-involvement human resource management practices on supply chain integration. International Journal of Physical Distribution \& Logistics Management, 45(8), 716-746.

Mangan, J., Lalwani, C., \& Lalwani, C. L. (2016). Global logistics and supply chain management. John Wiley \& Sons.

Menon, S. T. (2012). Human resource practices, supply chain performance, and wellbeing. International Journal of Manpower, 33(7), 769-785. 
News, A. (2016). Jeddah Port Crisis Worsens; Transport Fees Rise $200 \%$. Retrieved from http://www.arabnews.com/news/456005

Nitzl, C., Roldan, J. L., \& Cepeda, G. (2016). Mediation analysis in partial least squares path modeling: Helping researchers discuss more sophisticated models. Industrial Management \& Data Systems, 116(9), 1849-1864.

Notteboom, T. E., \& Rodrigue, J.-P. (2005). Port regionalization: towards a new phase in port development. Maritime Policy \& Management, 32(3), 297-313.

Pettit, S., \& Beresford, A. (2009). Critical success factors in the context of humanitarian aid supply chains. International Journal of Physical Distribution \& Logistics Management, 39(6), 450-468.

Preacher, K. J., Rucker, D. D., \& Hayes, A. F. (2007). Addressing moderated mediation hypotheses: Theory, methods, and prescriptions. Multivariate Behavioral Research, 42(1), 185-227.

Sánchez-Marín, G., Meroño-Cerdán, Á. L., \& Carrasco-Hernández, A. J. (2017). Formalized HR practices and firm performance: an empirical comparison of family and non-family firms. The International Journal of Human Resource Management, 1-27.

Scarbrough, H. (2000). The HR implications of supply chain relationships. Human Resource Management Journal, 10(1), 5-17.

Schuler, R. S., \& MacMillan, I. C. (1984). Gaining competitive advantage through human resource management practices. Human Resource Management, 23(3), 241-255.

Seo, Y.-J., Dinwoodie, J., \& Roe, M. (2016). The influence of supply chain collaboration on collaborative advantage and port performance in maritime logistics. International Journal of Logistics Research and Applications, 19(6), 562-582.

Shub, A. N., \& Stonebraker, P. W. (2009). The human impact on supply chains: evaluating the importance of "soft" areas on integration and performance. Supply Chain Management: An International Journal, 14(1), 31-40.

Song, D.-W., \& Parola, F. (2015). Strategising port logistics management and operations for value creation in global supply chains. Taylor \& Francis.

Thai, V., \& Jie, F. (2018). The impact of total quality management and supply chain integration on firm performance of container shipping companies in Singapore. Asia Pacific Journal of Marketing and Logistics, 30(3), 605-626.

Tongzon, J. L., \& Sawant, L. (2007). Port choice in a competitive environment: from the shipping lines' perspective. Applied Economics, 39(4), 477-492.

Wang, J. J., \& Cheng, M. C. (2010). From a hub port city to a global supply chain management center: a case study of Hong Kong. Journal of Transport Geography, 18(1), 104-115. 


\section{Appendix}

\section{Scale of the study}

HRP (Huo et al., 2015; Sánchez-Marín et al., 2017)

$\mathrm{S} \& \mathrm{C} 1$ : There is a rigorous selection process.

S\&C2: The selection of employees is based on skills required for the position.

S\&C3: The selection of potential employees is matched to business development.

EP1: Our plant forms teams to solve problems.

EP2: During the past 3 years, many problems have been solved through small group sessions.

EP3: Problem-solving teams have helped improve manufacturing processes at this plant.

EP 4: Charts showing defect rates are posted on the shop floor.

EP 5: Charts showing schedule compliance are posted on the shop floor.

EP 6: Charts plotting the frequency of machine breakdowns are posted on the shop floor.

EP 7: Information on quality performance is readily available to employees.

EP 8: Information on productivity is readily available to employees.

PSCI (Flynn et al., 2010)

SI1: Degree of sharing information to major suppliers through information technologies.

SI2: Degree of strategic partnership with suppliers.

SI3: Degree of joint planning with suppliers to maintain rapid response ordering process.

SI4: Degree of suppliers' involvement in work planning and development of services.

CI1: Degree of sharing with major customers about market updates.

CI2: Degree of sharing information to major customers through information technologies.

CI3: Degree of joint planning and design of work process with major customers.

CI4: Degree of customers' involvement in work planning and service development.

PP (Seo et al., 2016)

PP1: Our port capacity of inland transport services is good.

PP2: Our port transportation time to hinterland is short.

PP3: Our port is compliant with security regulations.

PP4: On our port the number of accidents is low.

PP5: On our port the terminal productivity is high.

PP6: Our port operating hours (24/7/365).

PP7: Our port total price is low.

PP8: Our port auxiliary service charge is low (pilotage, towage, customers). 
PP9: our port handles cargo on time as customers require.

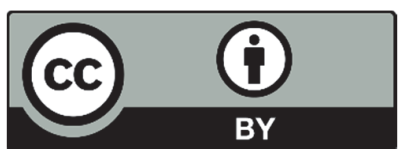

(C) 2019 by the authors; licensee Growing Science, Canada. This is an open access article distributed under the terms and conditions of the Creative Commons Attribution (CC-BY) license (http://creativecommons.org/licenses/by/4.0/). 